Joseph Bayley, M.R.C.S. Eng., has been appointed Resident Mledical Superintendent to the Northampton General Lunatic Asylum.

T. N. Brushfield, M.D. St. And., Medical Superintendent of the Cheshire Lunatic Asylum, has been elected to the office of Medical Superintendent of the Surrey Additional Lunatic Asylum, at Brookwood, near Woking.

J. T. Hingston, M.R.C.S.E , late Assistant Medical Officer North Riding of Yorkshire Lunatic Asylum, has been elected House Surgeon of the Northampton General Lunatic Asylum.

II. R. Ley, M.R.C.S.E., has been appointed Medical Superiutendent of the Salop and Montgomery Counties' Lunatic Asylum.

Samuel Hyde Macpherson, M.R.C.S., has beeu appointed Resident Medicul Superintendent of the Borough Lunatic Asylum, St. Augustine's, Norwich.

?.

\title{
Obituary.
}

At Church Stretton, Shropshire, Samuel Glover Bakewell, M.D. Edin., aged 55, on the 30th August.

At Bethlehem Hospital, William Helps, M.D. St. And., F.R.C.P. Edin., Resident Physician of the Hospital, aged 37, on the 7th Norember.

At Hardingstone, on the 17th December, Edin Wing, M.D. Lond., late Nedical Superintendent of the General Lunatic Asylum, Northampton, aged 47.

\section{Notice to Correspondents.}

English books for review, pamphlets, exchange journals, \&c., to be sent either by book-post to Dr. Robertson, Hayward's Heath. Sussex; or to the care of the publishers of the Journal, Messrs. Churchill and Sons, New Burlington Street. French, German, and American publications may be forwarded to Dr. Robertson, by foreign book-post, or to Messrs. Williams and Norgate, Henrietta Street, Covent Garden, to the care of their German, French, and American agents, Mr. Hartmann, Leipzig; M. Borrari, 9, Rue de St. Pìres, Paris ; Messrs. Westermann and Co., Broadway, New York.

The copies of The Journal of MFental Science are regularly sent by Book post to the ordinary Nembers of the Association, and to our Home and Foreign Correspondents, and we shall be glad to be informed of any irregularity in their receipt.

The following EXCHANGE JOURNALS have been regularly received since our last publication :

The Annales Medico-Psychologiques; the Zeitschrift fuir Psychiatrie; the Correspondenz Blatt der deutschen Gesellschaft für Psychyatrie; Archiv für Psychiatrie; the Irren Freund; Journal de Médecine MIentale; Archivio Italiuno per le Malaltie Neroose e per le Alienazioni Mentali; Mfedicinische Ahrenlese; Medizinische Jahrbücher; Zeitschrifl der $K . K$. Gesellschaft der Lerzto in Wien; 